\title{
PORNOCHANCHADA: DOCE SABOR DA TRANSGRESSÃO
}

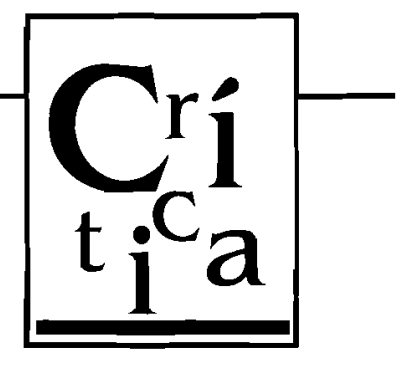

\section{Ao invés de ser desprezada, a pornochanchada - gênero que marcou o cinema nacional nos anos 70 - deve ser observada em relação ao falso moralismo e ao conservadorismo da sociedade brasileira}

Anos 70. Enquanto nas ruas ecoavam os brados dos que se proclamavam os salvadores da pátria; enquanto nos porões eram amordaçados os gritos dos que eram confinados por discordarem; no escurinho dos cinemas, os brados e gritos eram maliciosamente substituídos por sussurros e suspiros de atrizes desnudas, e de incansáveis garanhões à busca de satisfação sexual.

Foi a explosão das chamadas pornochanchadas. Nunca o cinema brasileiro produziu tanto e para um público tão numeroso. Foi o verdadeiro reatamento do cinema nacional com seu público, especialmente após o divórcio que se verificou entre esse público e as propostas do Cinema Novo.

A comédia, elemento sempre de muito sucesso em nossa cinematografia, como bem comprovam as chanchadas dos anos 40 e 50, aliou-se ao erotismo com tanto sucesso que essa reunião se tornou verdadeiramente, para o grande público, sinônimo de cinema brasileiro. Dizer, a partir de então, que o cinema nacional "só mostrava mulher pelada", tornou-se lugar comum.

Com precaríssimos esquemas de produção e divulgação e enfrentando inicialmente dificuldades junto aos distribuidores e controlados pela indústria cinematográfica norte-americana a pornochanchada conseguiu retomar as telas brasileiras com muita força.
Sem qualquer timidez, nossas salas exibiam títulos tais como Os mansos, Lua de mel e amendoim, As cangaceiras eróticas, Essa mulher é minha e dos amigos, Como era boa a nossa empregada e outros, dentre centenas que foram produzidos. Esses, em alguns casos, deixavam para trás, em termos de bilheteria, algumas das bem comportadas, caríssimas e bem divulgadas produções norte-americanas.

As razões para tamanho sucesso encontram muitas explicações: a maior parte delas verdadeiras, mas nenhuma capaz de explicar isoladamente o fenômeno.

A mais comum e óbvia é aquela que atribui ao Estado autoritário a intenção de controlar o nível cultural da população, mantendo-a suficientemente dócil e imbecilizada para facilitar os processos de dominação. Assim, a pornochanchada estaria facilitando a circulação de besteiras e futilidades para um povo cujos maiores valores estariam no futebol, na "sacanagem" e na cerveja. Evidentemente que tal explicação, além de incorrer em preconceitos, revela uma certa dose de ingenuidade.

\section{O AUTOR}

Valter Vicente Sales Filho

Comunicador Social e Mestre em Comunicação Social pela ECA-USP. 


\section{AUTORITARISMO E PORNOCHANCHADA}

O Estado autoritário, considerando que as atividades culturais se relacionavam intrinsecamente à idcologia da Segurança Nacional, procurou interferir direramente na produçāo cultural. Na ácea cinematográfica foram criados mecanismos de incentivo à produção, que, em verdade, significaram tambêm a criação de empecilhos e dificuldades aos cineastás opositores ao regime, tais como Glauber Rocha, Carlos Barreto e outros. Assim, esses mecanismos de proteção e incentivo do Estado ao cinema acabaram por gerar, de um lado, o quase aniquilamento de grupos opositores e, de outro, a dependência de cimeastas simparizantes, que adequavam seus trabalhos aos temas e às propostas do poder cential, à busca de financiamentos e acesso ao mercado exibidor.

Entre algumas medidas implantadas pelo Estado Autoritário temos a destacar a obrigatoriedade de exibição de filmes brasileiros (que variou de 56 dias de exibição em 1967 a 112 dias em 1975), a obrigatoriedade de copiagem de lilmes estrangeiros em laborátórios nacionais, a introdução do controle centralizado de vendas de ingressos e outras.

É claro que a pornochanchada se beneficiou dessas condiç̃es impostas pelo regime militar, mas sua expansão se deu quase que à margem das políticas oficiais.

Ela ocupou sorrateiramente o espaço destinado às escassas produções mais ao gosto e padrão estético pretendjdos pelo Estado autoritário, sintetizados em produçōes como Independência ou morte, que ressaltava os mitos e valores da história oficial. $O$ sucesso da pornochanchada foi resultado da astúcia e malícia de cineastas cujo maior interesse estava voltado para as vultosas cifras

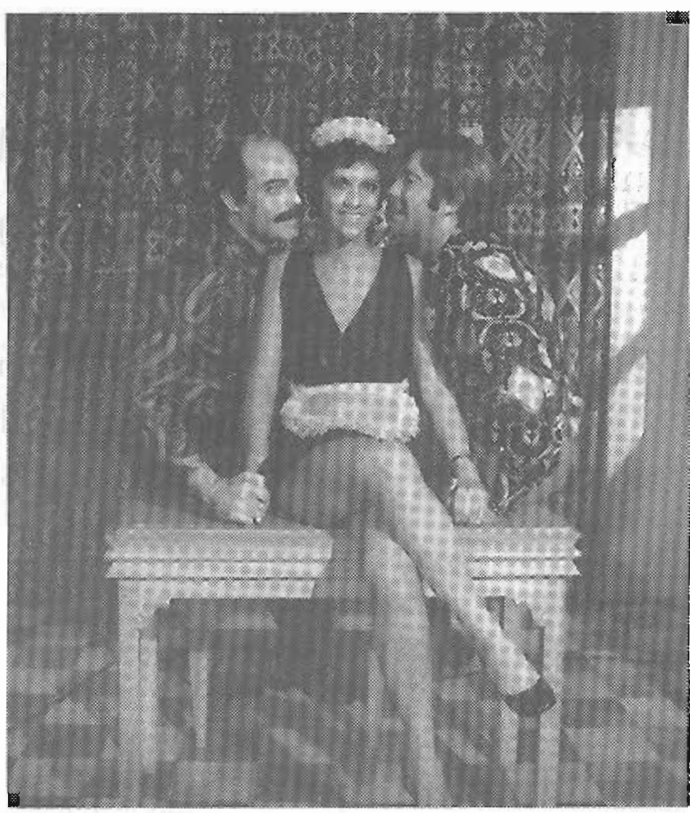

Rubem de [ialco, Rosina Morla e Eniliano Queiror no filme Ĺma pantera em ininla cama produça de 1971, roteciro, direçūto e produção de Carlos Hugo Christensen.'

que o gênero proporcionou, combinando produções baratas com alta rentabilidade.

Alguns filmes permaneciam em cartaz por períodos até maiores que o mínimo obrigatório, o que passou a despertar a atenção até mesmo de distribuidores e empresas estrangeiras, interessadas em produzir aqui filmes do gênero - fato inédito na história de nosso cinema que na maioria das vezes, se viu esmagado pela avalanche de produções norte-americanas, que chegam aqui a custos bem reduzidos.

Além de qualquer visão funcionalista sobre a utilização desses filmes como apaziguadores das massas, ou da expansão proporcionada pelos incentivos do Eslado, um outro importante motivo pode explicar o sucesso das pornochanchadas: o da própria identificação do público com os conteúdos presentes.

Paulo Emílio Salles Gomes, um dos mais referenciados estudiosos do cinema

1. In: PAIVA. Salvyano Cavalcanti de. História ilustrada dos filmes brasileiros 1929-1988. Rio de Yaneiro: Francisco Alves, 1989. p. 152 
nacional, chama a atenção para o valor documental desses filmes que retrataram, com fidelidade, a sexualidade brasileira.

Ora, a produção de pornochanchadas foi bastante criticada pelos setores mais conservadores e mais intelectualizados, especialmente por estar recheada de aspectos como a banalização da sexualidade, a exploração do corpo da mulher, o machismo, o falocentrismo e outros. Parecenos, entretanto, que esses filmes não fizeram outra coisa senão retratar esses aspectos de nosso cotidiano com incrível ingenuidade e, por isso mesmo, de forma tão clara e escandalosa, o que acabou por gerar irados ataques.

Evidente que a pornochanchada não questiona, não analisa e não adota uma postura crítica sobre tais aspectos. Apenas os expõe de forma escancarada, o que a tornou, na expressão cunhada pelo crítico Jean Claude Bernardet, "o bode expiatório" do que consideramos nossas mazelas culturais. Se existem filmes pornográficos, não são eles que distorcem a sexualidade, eles existem justamente em função de uma sexualidade já distorcida. Pornográfica é a forma de relacionamento das pessoas com sua sexualidade: elegendo modelos de corpos ideais, subtraindo a sensualidade de todo o corpo e reduzindo-a unicamente aos órgãos sexuais, reduzindo o encontro entre parceiros a uma relação de posse, num contexto de poder e de dominação.

Os conteúdos presentes nesses filmes, e em muitos outros produtos da cultura de massa, antes de existirem em função de algum interesse consciente, são condicionados inconscientemente pela sociedade que os concebe.

Assim, é sempre bom despertar a atenção para os produtos com grande aceitação popular, como as telenovelas, os programas de auditório, os filmes de violência ou as próprias pornochanchadas. A aceitação, se bem que condicionada por imposições de mercado, reflete também, e principalmente, a identificação dos valores e conceitos contidos nesses produtos com os do público receptor.

\section{FALSO MORALISMO E CONSERVADORISMO}

Essas colocações parecem traçar um panorama sombrio sobre nossas relações culturais, e em especial nas questões de sexualidade no que se refere ao caso específico da pornochanchada.

\section{Parece haver uma notável contradição entre o que se determina dentro dos parâ- metros morais e o que efetivamente acon- tece no cotidiano.}

Em uma primeira análise, o que é retratado na pornochanchada nos faz concluir que o que mais distingue nossa sexualidade é um certo desejo pela transgressão. O casamento é indissolúvel (até certo ponto), a fidelidade é inquestionável (até que apareça uma primeira oportunidade), a integridade da família é suprema (às vezes), somos todos católicos (alguém se lembra?). No universo temático das pornochanchadas estão registradas várias entrelinhas, que parecem demonstrar que nossa relação com as coisas não é de tanta submissão quanto poderíamos imaginar. Se existem normas, por que não desobedecê-las? Cabe então uma questão: se constantemente transgredimos as normas, por que nossa relação com o poder nunca se altera? Por que nossos valores nunca se alteram? Será que realmente acreditamos que as normas e o poder estão aí para serem desafiados? Uma análise mais detalhada desses filmes, entretanto, literalmente desmonta e faz desmoronar qualquer idéia sobre a transgressão que até agora tem sorrateiramente caracterizado a identidade brasileira. Parece que o que 
mais claramente nos distingue é o conservadorismo. Conservadorismo não apenas no sentido da preservação dos chamados bons costumes, mas sim de todas as idéias e conceitos em que estamos mergulhados: sejam eles bons costumes, sejam preconceitos, ou estereótipos.

É comum no universo das pornochanchadas um desfile de obsessões e intrigas, de mulheres ávidas por aventuras sexuais, de maridos traídos, de tresloucados personagens homossexuais, entre outros.

Numa das muitas pornochanchadas, um personagem masculino começa a ficar atordoado por uma paixão que começa a manifestar por um rapaz. Atentado ao machismo? Não. $\mathrm{Na}$ verdade esse rapaz era uma mocinha que, para vencer na vida, traveste-se. Atormentado por essa paixão, o personagem, no entanto, resplandece de felicidade, quando no final descobre que o rapaz era uma mocinha: "Puxa! Ainda bem que você é mulher!". A integridade do macho está revigorada. No filme Ainda agarro este machão, um estúdio fotográfico é o cenário para o desfile constante de atrizes com seus bumbuns e seios desnudos. Sempre conversam e brincam: gargalhadas estrondosas, pernas para o alto, unhas sendo lixadas: "Com quem você dormiu esta noite, queridinha?", interroga uma dessas atrizes. Mas, numa cena com pretensa intensidade dramática, uma das modelos confessa em tom desesperado: "É uma barra, menina. Enfrentar essa vida não é fácil. Você perisa que eu sou feliz?". Já no filme As viúvas eróticas, um espírito observa sua esposa ainda viva, que se entrega a um novo amante, empenhando-se então para evitar o sucesso da relação. A viúva, que teme por algo estranho que esteja acontecendo no apartamento, não consegue se relacionar, irritando o parceiro: "Vai dar como toda viúva que se preza".
Não são raros os filmes em que rapazes e moças se deliciam em seqüenciais e mirabolantes orgias, mas que, em compensação, estão sempre à procura de um parceiro ideal, evidentemente virgem, para um compromisso mais sério e um fantástico happy end (final feliz), através do casamento.

É evidente que o conservadorismo não se refere apenas aos aspectos morais consensualmente considerados adequados como os que exemplificamos acima, mas também engloba e cristaliza preconceitos envolvendo classes sociais, distinções entre os sexos, distinções entre faixas etárias, profissões, raças, etnias e outros aspectos. Assim, o conservadorismo que transparece na pornochanchada não se refere unicamente à sexualidade - provavelmente nem é aí que ele se origina -, mas de qualquer forma se observa que ele se instala nas relações de poder, conservando e mantendo intactos seus aspectos positivos ou negativos. Dessa forma, a transgressão parece resultar inócua, ou antes, ela sequer existe.

Não há portanto nada de perverso na pornochanchada, ela apenas ressalta os contextos morais, pelo sublinhado dos contextos de ilegalidade. Ela teve a inconsciente coragem de ressaltar, relatar e delatar o que em muitos outros produtos, como as telenovelas, os programas de auditório ou as revistas femininas, aparece apenas de forma velada, mais dourada e finamente perfumada. Se pouco contribuíram para a evolução da linguagem cinematográfica, ou do questionamento de aspectos sociais, não há como negar o valor desses filmes enquanto documentos históri$\cos$, notadamente expurgados justamente por apresentarem, em technicolor, aquilo que sempre procuramos ocultar. Assim, na pornochanchada não há nada com o que nos espantar: está tudo dentro. Dentro das normas. 